\title{
INTERACTION BETWEEN HABITAT CHARACTERISTICS AND INSECT DIVERSITY USING GROUND BEETLES (COLEOPTERA: CARABIDAE) AND ANTS (HYMENOPTERA: FORMICIDAE) WITHIN A VARIETY OF AGRICULTURAL HABITATS
}

\author{
MAGAGULA, C. N. ${ }^{1 *}$-NZIMA, B. A. ${ }^{2}$ \\ ${ }^{I}$ Department of Biological Sciences, University of Swaziland. P/Bag 4, Kwaluseni. Swaziland. \\ (phone: +268-2517-0292; fax: +268-2517 0001) \\ ${ }^{2}$ Malkerns Research Station, Ministry of Agriculture, Malkerns. Swaziland. \\ (phone: +268-2527-4077; fax: +268-2527 4070) \\ *Corresponding author \\ e-mail: cebisile@uniswa.sz \\ (Received $5^{\text {th }}$ Aug 2014; accepted $11^{\text {th }}$ Sep 2014)
}

\begin{abstract}
Heterogenous agroecosystems have the capacity to maintain high insect diversity despite alterations due to human activities. The distribution of carabid beetles and ants within a variety of habitat mosaics was monitored at two climatically distinct locations. Both insect Families were monitored to compare community similarities between habitats, within and between the two sampling locations. Species occurrences were significantly different between the two locations $(\mathrm{p}<0.05)$, with distinct patterns of distribution, resulting in high dissimilarity between locations and habitats sampled. While the lowveld had highest populations and diversity of both ants and carabid beetles in unmanaged habitats, the middleveld had high carabid beetle diversity in managed habitat and populations in unmanaged habitat, while ant populations and diversity were highest in an unmanaged habitat. Although the two locations had no carabid beetle species in common, they had a few ant species in common. Due to their abundance, diversity and relation to management, both insect Families have the potential to be used as indicators in the locations assessed..
\end{abstract}

Keywords: agroecosystems, carabid beetles, ants, habitat management, diversity, conservation

\section{Introduction}

Land conversion for agricultural purposes affects large parts of terrestrial habitats so an understanding of its influence on biodiversity is critical (Tscharntke et al., 2005). A primary challenge in this is an understanding of how habitat alteration affects biodiversity, particularly since certain habitat characteristics and quality are known to be important drivers of local species richness (Daube et al., 2005; Weibull et al., 2003; Barragon et al., 2011). Variation in species of soil macroarthropods is related to a number of factors at habitat scale, such as land use and composition of the surrounding matrix. Habitat quality and soil conditions are of great importance to a number of epigaeic invertebrates including ants, beetles, butterflies and plants (Weibull et al., 2003; Daube et al., 2005). Differences in local species richness may be caused by processes at larger spatial scales and arthropod species, of differing size and mobility, can be regulated by different processes at the same spatial scale, e.g. carabids disperse by walking during foraging and egg-laying (although many species are capable of flight) while ants do so from mating flights of alates (Dauber et al., 2005). It is important to understand how heterogeneous landscapes may serve to maintain biodiversity and how this diversity may be affected by processes of 
transformation from traditional agroecosystems to modern ones (Perfecto et al., 1997). Since natural landscapes are usually embedded within managed agroecosystems nowadays, management practices in these can have an impact on the ability of the natural landscapes to sustain biological diversity at landscape levels (Perfecto et al., 1997). Diverse agroecosystems have the capacity to maintain high arthropod diversity despite transformation. Arthropods, which include insects, are good indicators of ecological condition since they are highly diverse and functionally important within ecosystems. Ground beetles (Coleoptera: Carabidae) and ants (Hymenoptera: Formicidae) are two invertebrates groups which have been studied within various ecosytems (Andersen et al., 2002; Gerlach et al., 2013). Ants are considered to be ecosystem engineers and are thus important components of ecosystems, constituting an important part of its animal biomass and have potential to be used as indicators (Fogariat, 1998; Peck et al., 1998; Anderson et al., 2002). This because they are capable of tracking environmental gradients and can be indicators of soil type. Carabids are also known to respond to different changes in landscape features and management (Weibull et al., 2003). Both carabids and ants are ubiquitous and abundant with known ecological relations, particularly in the northern hemisphere (Magura et al., 2000; Andersen and Majer, 2004; Underwood and Fisher, 2006). Research has been on the individual Families and this study was carried out to assess species distribution between different habitat mosaics at two distinct sampling locations for both insect Families. Since species richness is related to habitat characteristics and land use as well as the composition of the surrounding matrix (Weibull et al., 2003; Dauber et al., 2005) various habitat and soil characteristics were also measured to ascertain if this applied in this environment. Small-scale mosaics of land use types enable comparison of habitat patches differing in composition without geographical differences which would cause major bias (Dauber et al., 2005).

\section{Materials and Methods}

The study was carried out at two agricultural research stations in Swaziland. Both research stations have a variety of both natural and manmade habitat mosaics and are subsequently referred to as the sampling locations. Malkerns Research Station (MRS) is located in the middleveld region $\left(26^{\circ} 33.3 \mathrm{~S}, 31^{\circ} 9.93 \mathrm{E} ; 739 \mathrm{~m}\right.$ asl $)$ with mean temperatures ranging between 15.7 to $26.3^{\circ} \mathrm{C}$ and rainfall $87.6 \mathrm{~mm}$ while the Lowveld Research Station (LES) is located in the lowveld region $\left(26^{\circ} 57.95 \mathrm{~S}, 31^{\circ} 31.52 \mathrm{E} ; 89 \mathrm{~m}\right.$ asl), with mean temperatures ranging between 19.2 to $30^{\circ} \mathrm{C}$ and rainfall of $30.1 \mathrm{~mm}$ and during the sampling period. Maize is the primary crop grown at MRS while cotton is grown in the lowveld, thus the selection of these as the plots areas. Cotton is a regulated crop and has regulated pest management schedule which was followed. An attempt was made to match sample similar habitats at each location and four distinct habitat types were selected at each location depending on availability as indicated in Table 1 .

Pitfall trapping was used to sample ground dwelling arthropods within the habitat patches. These are a convenient method of catching various epigaeic arthropods and provide information on the relative species abundance within the area sampled (Henschel et al., 2010). Within each sampling habitat, pitfall traps were placed $15 \mathrm{~m}$ from edge and along three $20 \mathrm{~m}$ long transects. For the maize and cotton plots, proportional distances were used since these had shorter dimensions than the unmanaged habitats. Each habitat thus had nine pitfall traps, resulting in 36 traps per 
location and 72 overall. Traps were half-filled with $70 \%$ ethylene glycol, which served as a preservative and were serviced fortnightly at each sampling locations. Sampling, carried out over one growing season (February to June), was begun four weeks after the maize had been planted and continued for 18 weeks, which was two weeks after the maize had been harvested.

Table 1. Decsription of sampling habitats within each sampling location

\begin{tabular}{|l|l|l|l|l|l|}
\hline \multicolumn{2}{|c|}{ MRS } & \multicolumn{1}{c|}{ LES } \\
\hline 1 & $\begin{array}{c}\text { Abbreviatio } \\
\text { Habitat }\end{array}$ & \multicolumn{1}{|c|}{ Description } & Habitat & Abbreviation & \multicolumn{1}{|c|}{ Description } \\
\hline 2 & MEB & $\begin{array}{l}\text { Eucalyptus border. No } \\
\text { plants for ground cover, } \\
\text { no litter cover }\end{array}$ & 6 & LGB & $\begin{array}{l}\text { Natural grassland, } \\
\text { fallow }\end{array}$ \\
\hline 3 & MGB & $\begin{array}{l}\text { Grass border between } \\
\text { maize plots. }\end{array}$ & 7 & LCP & $\begin{array}{l}\text { Grass border } \\
\text { between plots }\end{array}$ \\
& $\begin{array}{l}\text { MNatton plot. } \\
\text { Pesticide } \\
\text { application as per } \\
\text { recommended } \\
\text { intervals } \\
\text { (fortnightly) and } \\
\text { weeding when } \\
\text { needed. }\end{array}$ \\
\hline 4 & MMP & $\begin{array}{l}\text { Maize plots. No } \\
\text { management thus } \\
\text { increasing ground cover } \\
\text { as maize matured }\end{array}$ & 8 & LPB & $\begin{array}{l}\text { Pine border } \\
\text { between sweet } \\
\text { potato plots. } \\
\text { Litter cover from } \\
\text { dropped leaves. }\end{array}$ \\
\hline
\end{tabular}

\section{Sampling procedure}

Morphospecies were used in separating the specimen collected for both Families. The carabids were subsequently identified at the Ditsong Museum of Natural History and the morphospecies were all matched to the identification list. While the ants were also identified at AfriBugs, the initial morphospecies were maintained since a recount was not possible due to the high number involved and morphospecies also provide accurate biodiversity information (Anderson et al. 2002). With the exception of two morphospecies, the majority of specimen had been separated properly thus their scientific. Where more than one species was found by the expert, the species combination is indicated.

\section{Habitat characteristics}

Habitat characteristics were noted at three stages during the experiment (beginning, middle and end) and these were the litter cover and insolation (\%) per square metre at each site. Standard soil sampling procedure was carried out, whereby $200 \mathrm{~g}$ of soil was sampled at a depth of $10 \mathrm{~cm}$ from different points at each habitat then mixed and analysed for various parameters at each site, i.e. $\mathrm{pH}$, nitrogen $(\%)$, phosphorus ( $\mathrm{ppm})$, EA (me\%) and Organic matter (\%). Monthly rainfall and temperature for each location were obtained from the national meteorological services. 


\section{Analyses}

Community analyses were carried to determine species distribution in all the habitats sampled at both sampling locations. Statistical analyses were carried out to assess differences in species dynamics between the two sampling locations and sampling habitats within each location as well as their interaction with the habitat characteristics measured. ANOVA (Statistix) was also used to determine differences between sampling occasions/weeks. Various modiles in PRIMER were used for community analyses, where the rank abundance curve, cluster analyses and ANOSIM were used. Simper was used to determine similarity between sampling habitats, by determining species typical of sampling locations and habitats. The same module also calculates levels of dissimilarity by determining species which are important for discriminating between the two sampling locations. Draughtsman plot was used to calculate Pearson's correlation coefficients between environmental variables measured and the species. Single species occurrences within each location were excluded in the analyses to avoid vagrant species.

\section{Results}

\section{Abundance and diversity of carabid beetles and ants}

A total of 218 (19 species) of carabid beetles (Table 2) and 16080 (25 species) ants (Table 3) were collected from both sampling locations, with the middleveld location having significantly higher populations than the lowveld location $(\mathrm{R}=0.392 ; \mathrm{p}=$ $0.001)$. Due to the very significant differences in the numbers and species composition between the two sampling locations and insect Families $(\mathrm{P}<<0.05)$ subsequent analyses were carried out separately for these. Abacetus cf percoides was the dominant carabid species, making up $30.28 \%$ of all carabid beetles collected. This was also the dominant species in the middleveld, making up 38.69\% of its carabid beetles while Chlaenius notabilis was the dominant carabid beetle species from the lowveld, making up $44 \%$ of its carabid beetles (Figure 1a; Table 2). Ants were dominated by the Morphospecies no. 1 at both locations (Figure 1b; Table 3).
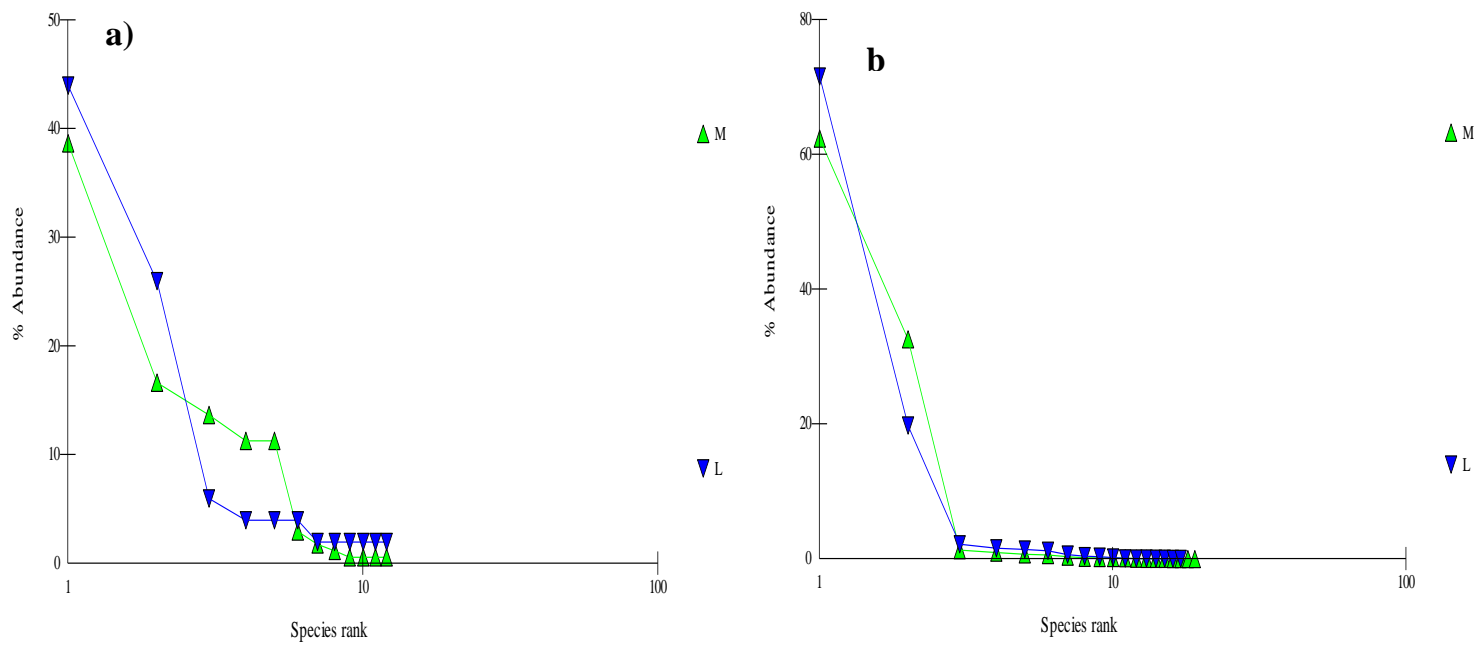

Figure1. Species rank abundance curve for a) carabid beetles and b) ants collected from both sampling locations. $M=M R S, L=L E S$ 
Table 2. Total carabid beetles collected from all habitats in both sampling locations. See Table 1 for habitat abbreviations

\begin{tabular}{|c|c|c|c|c|c|c|c|c|c|c|c|c|c|c|}
\hline \multirow[t]{2}{*}{ Species code } & \multicolumn{6}{|c|}{ MRS } & \multicolumn{6}{|c|}{ LES } & \multicolumn{2}{|c|}{ Total } \\
\hline & NG & EB & GB & MP & $\Sigma$ & $\begin{array}{l}\% \text { of } \\
\text { sample }\end{array}$ & NG & GB & $\mathrm{CP}$ & PB & $\Sigma$ & $\begin{array}{l}\% \text { of } \\
\text { sample }\end{array}$ & $\sum \Sigma$ & $\begin{array}{l}\text { Overall } \\
\%\end{array}$ \\
\hline $\begin{array}{ll}\text { Abacetus } & \text { cf. } \\
\text { percoides Frm }\end{array}$ & 5 & 0 & 10 & 50 & 65 & 38.69 & 0 & 1 & 0 & 0 & 1 & 2.00 & 66 & 30.28 \\
\hline $\begin{array}{l}\text { Chlaenius } \\
\text { cylindricollis }\end{array}$ & 0 & 0 & 15 & 13 & 28 & 16.67 & 0 & 0 & 0 & 0 & 0 & 0.00 & 28 & 12.84 \\
\hline $\begin{array}{l}\text { Parophonus } \\
\text { tomentosus Dej. }\end{array}$ & 1 & 1 & 2 & 19 & 23 & 13.69 & 0 & 0 & 0 & 0 & 0 & 0.00 & 23 & 10.55 \\
\hline $\begin{array}{l}\text { Chlaenius notabilis } \\
\text { Lafert }\end{array}$ & 0 & 1 & 0 & 0 & 1 & 0.60 & 9 & 11 & 2 & 0 & 22 & 44.00 & 23 & 10.55 \\
\hline Unidentified $s p . \# 1$ & 0 & 0 & 4 & 15 & 19 & 11.31 & 1 & 0 & 0 & 0 & 1 & 2.00 & 20 & 9.17 \\
\hline $\begin{array}{l}\text { Abacetus optimus } \\
\text { Per. }\end{array}$ & 0 & 0 & 18 & 1 & 19 & 11.31 & 0 & 0 & 0 & 0 & 0 & 0.00 & 19 & 8.72 \\
\hline $\begin{array}{l}\text { Omostropus } \\
\text { mandibularis Roth }\end{array}$ & 0 & 0 & 0 & 0 & 0 & 0.00 & 5 & 5 & 3 & 0 & 13 & 26.00 & 13 & 5.96 \\
\hline Scarites sp. & 0 & 0 & 3 & 2 & 5 & 2.98 & 0 & 0 & 0 & 0 & 0 & 0.00 & 5 & 2.29 \\
\hline Progonochaetus sp. & 0 & 0 & 0 & 0 & 0 & 0.00 & 2 & 1 & 0 & 0 & 3 & 6.00 & 3 & 1.38 \\
\hline $\begin{array}{l}\text { Chlaenius dusaulti } \\
\text { (L. Dufour) }\end{array}$ & 0 & 0 & 0 & 1 & 1 & 0.60 & 0 & 1 & 0 & 1 & 2 & 4.00 & 3 & 1.38 \\
\hline Brachinus sp. & 0 & 0 & 3 & 0 & 3 & 1.79 & 0 & 0 & 0 & 0 & 0 & 0.00 & 3 & 1.38 \\
\hline Chlaenius laetus Fab. & 0 & 1 & 0 & 1 & 2 & 1.19 & 0 & 0 & 0 & 0 & 0 & 0.00 & 2 & 0.92 \\
\hline $\begin{array}{l}\text { Harpalus hybridus } \\
\text { Boh. }\end{array}$ & 0 & 0 & 0 & 0 & 0 & 0.00 & 0 & 1 & 1 & 0 & 2 & 4.00 & 2 & 0.92 \\
\hline Dromica simplex & 0 & 1 & 0 & 0 & 1 & 0.60 & 1 & 0 & 0 & 0 & 1 & 2.00 & 2 & 0.92 \\
\hline $\begin{array}{l}\text { Callistoides cf. } \\
\text { pulchellus Boheman }\end{array}$ & 0 & 0 & 0 & 0 & 0 & 0.00 & 2 & 0 & 0 & 0 & 2 & 4.00 & 2 & 0.92 \\
\hline $\begin{array}{l}\text { Lophyra } \\
\text { fasciculicornis } \\
\text { Barker }\end{array}$ & 0 & 0 & 0 & 0 & 0 & 0.00 & 0 & 1 & 0 & 0 & 1 & 2.00 & 1 & 0.46 \\
\hline UnIC2 & 0 & 0 & 1 & 0 & 1 & 0.60 & 0 & 0 & 0 & 0 & 0 & 0.00 & 1 & 0.46 \\
\hline $\begin{array}{l}\text { Amblyostoma } s p . \\
\text { Erichson }\end{array}$ & 0 & 0 & 0 & 0 & 0 & 0.00 & 0 & 0 & 1 & 0 & 1 & 2.00 & 1 & 0.46 \\
\hline $\begin{array}{l}\text { Cypholoba } \\
\text { graphipteroides } \\
\text { Guerin }\end{array}$ & 0 & 0 & 0 & 0 & 0 & 0.00 & 0 & 0 & 0 & 1 & 1 & 2.00 & 1 & 0.46 \\
\hline$N$ & 6 & 4 & 56 & 102 & 168 & & 20 & 21 & 7 & 2 & 50 & & 218 & \\
\hline$S$ & 2 & 4 & 8 & 8 & 12 & & 6 & 7 & 4 & 2 & 12 & & 19 & \\
\hline Richness $d$ & 0.56 & 2.16 & 1.74 & 1.51 & 2.15 & & 1.67 & 1.97 & 1.54 & 1.44 & 2.18 & & 3.34 & \\
\hline Evenness $J^{\prime}$ & 0.65 & 1 & 0.83 & 0.68 & 0.72 & & 0.82 & 0.72 & 0.92 & 1 & 0.70 & & 0.76 & \\
\hline Shannon $H^{\prime}$ & 0.45 & 1.39 & 1.72 & 1.42 & 1.78 & & 1.47 & 1.41 & 1.28 & 0.69 & 1.74 & & 2.23 & \\
\hline
\end{tabular}

There were also significant differences in the number of carabid beetles and ants collected over the sampling period at both locations $(p<<0.05)$ (Figure 2). Both Families had an initial increase during the second and third sampling occasions then subsequently declined.

There were significant differences in insect populations between sampling habitats at each location. In the middleveld, the grass border had significantly higher number of ants $(\mathrm{R}=0.289, \mathrm{p}=0.001)$ while the same was true of the carabid beetles in the maize plot $(\mathrm{R}=0.0557 ; \mathrm{p}=0.001)$. Comparatively, the lowveld had higher numbers of ants in the natural grassland and more carabid beetles in the grass border and natural grassland. A Principal component analysis (PCA) of the diversity indices for each sampling habitat was used to present the biodiversity information in a composite form for all the habitats sampled. For the carabid beetles, the PCA accounted for $91.6 \%$ of the information in the diversity indices where the first axis was of decreasing total species, diversity and number of beetles, while the second was of decreasing species evenness and richness (Figure $3 a$ ). The natural grassland in the middleveld had low richness and evenness, while the maize plot also had low evenness but the highest number of carabids collected. For ants, the PCA accounted for $87 \%$ of the information, where the first axis was of decreasing species evenness, richness and diversity while the second axis was of 
decreasing total number and species of ants collected (Figure 3b). The eucalyptus border had the highest species evenness despite low diversity and number of insects collected due to the absence of any dominant species while the maize plot at MRS had the lowest due to dominance by Myrmicinae ants, which also dominated the cotton plot at LES.
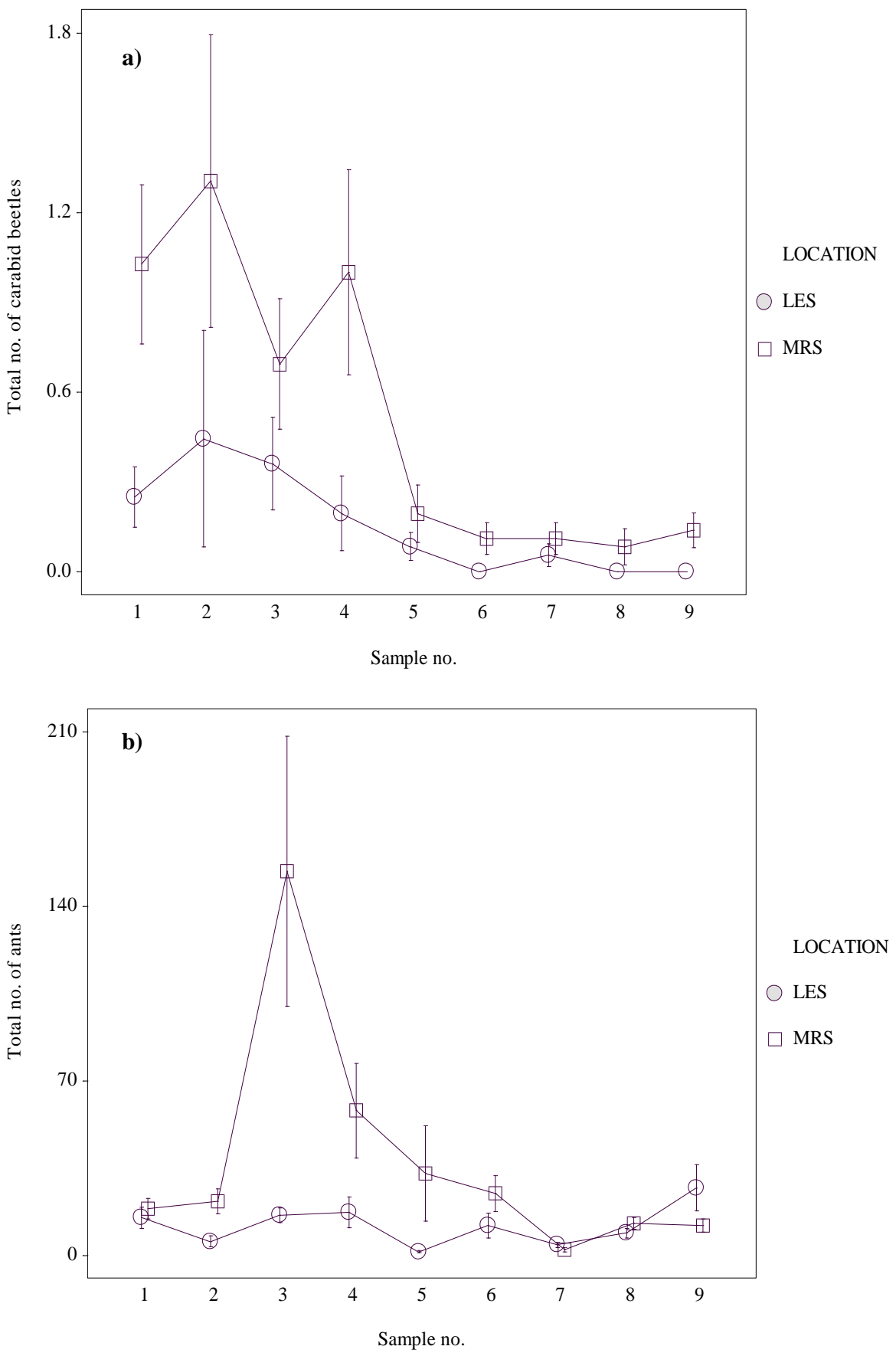

Figure 2. Total number of a) carabid beetles ( SE) and b) ants collected from both sampling locations over the sampling period 
Table 3. Total ants collected from all habitats in both sampling locations. See Table 1 for habitat abbreviations

\begin{tabular}{|c|c|c|c|c|c|c|c|c|c|c|c|c|c|c|}
\hline \multirow[t]{2}{*}{ Species code } & \multicolumn{6}{|c|}{ MRS } & \multicolumn{6}{|c|}{ LES } & \multicolumn{2}{|c|}{ Total } \\
\hline & NG & $\mathrm{EB}$ & GB & $\mathrm{MP}$ & $\Sigma$ & $\begin{array}{c}\% \text { of } \\
\text { sample }\end{array}$ & NG & GB & $\mathrm{CP}$ & PB & $\Sigma$ & $\begin{array}{c}\% \text { of } \\
\text { sample }\end{array}$ & $\sum \Sigma$ & $\begin{array}{c}\text { Overall } \\
\%\end{array}$ \\
\hline $\begin{array}{l}\text { Morphospecies no. } 1 \\
\text { (Myrmircinae) }\end{array}$ & 399 & 170 & 5917 & 1108 & 7594 & 62.40 & 325 & 614 & 977 & 884 & 2800 & 71.61 & 10394 & 64.64 \\
\hline Anolepis custodiens & 3872 & 73 & 26 & 0 & 3971 & 32.63 & 19 & 13 & 27 & 4 & 63 & 1.61 & 4034 & 25.09 \\
\hline Pheidole & 52 & 32 & 2 & 2 & 88 & 0.72 & 672 & 45 & 21 & 37 & 775 & 19.82 & 863 & 5.37 \\
\hline Camponotus $A F R C-z a 42$ & 7 & 0 & 156 & 0 & 163 & 1.34 & 1 & 0 & 0 & 1 & 2 & 0.05 & 165 & 1.03 \\
\hline Leptogynys intermedia & 110 & 5 & 0 & 3 & 118 & 0.97 & 0 & 0 & 0 & 0 & 0 & 0.00 & 118 & 0.73 \\
\hline Camponotus AFRC_zal2 & 1 & 5 & 13 & 2 & 21 & 0.17 & 37 & 40 & 7 & 2 & 86 & 2.20 & 107 & 0.67 \\
\hline Pohrhachis schistacea & 1 & 0 & 53 & 21 & 75 & 0.62 & 1 & 2 & 0 & 6 & 9 & 0.23 & 84 & 0.52 \\
\hline Aenictus AFRC_za03 & 0 & 0 & 1 & 1 & 2 & 0.02 & 34 & 8 & 0 & 14 & 56 & 1.43 & 58 & 0.36 \\
\hline Ocymyrmex fortior & 0 & 0 & 0 & 0 & 0 & 0.00 & 37 & 9 & 1 & 1 & 48 & 1.23 & 48 & 0.30 \\
\hline Tetramorium notiale & 38 & 7 & 0 & 0 & 45 & 0.37 & 0 & 0 & 0 & 1 & 1 & 0.03 & 46 & 0.29 \\
\hline Morphospecies no. 11 & 17 & 0 & 0 & 0 & 17 & 0.14 & 22 & 2 & 1 & 1 & 26 & 0.66 & 43 & 0.27 \\
\hline Technomrymex pallipes & 13 & 11 & 0 & 0 & 24 & 0.20 & 4 & 3 & 1 & 6 & 14 & 0.36 & 38 & 0.24 \\
\hline Cerapachys wroughtoni & 0 & 21 & 0 & 0 & 21 & 0.17 & 0 & 0 & 0 & 0 & 0 & 0.00 & 21 & 0.13 \\
\hline Odontomachus troglodytes & 0 & 0 & 0 & 0 & 0 & 0.00 & 17 & 0 & 0 & 0 & 17 & 0.43 & 17 & 0.11 \\
\hline Nylanderia natalens is & 9 & 0 & 0 & 0 & 9 & 0.07 & 0 & 0 & 0 & 0 & 0 & 0.00 & 9 & 0.06 \\
\hline Leptogynys schwabi & 5 & 0 & 0 & 0 & 5 & 0.04 & 1 & 2 & 0 & 0 & 3 & 0.08 & 8 & 0.05 \\
\hline Lepisiota crinita & 4 & 1 & 0 & 1 & 6 & 0.05 & 0 & 0 & 0 & 0 & 0 & 0.00 & 6 & 0.04 \\
\hline Camponotus $A F R C-z a 53$ & 1 & 0 & 1 & 2 & 4 & 0.03 & 0 & 0 & 0 & 0 & 0 & 0.00 & 4 & 0.02 \\
\hline Tetramorium sericeiventre & 0 & 0 & 0 & 0 & 0 & 0.00 & 4 & 0 & 0 & 0 & 4 & 0.10 & 4 & 0.02 \\
\hline Cataulacus traegaordo & 3 & 0 & 0 & 0 & 3 & 0.02 & 0 & 0 & 0 & 0 & 0 & 0.00 & 3 & 0.02 \\
\hline Camponotus mayri & 0 & 0 & 0 & 0 & 0 & 0.00 & 3 & 0 & 0 & 0 & 3 & 0.08 & 3 & 0.02 \\
\hline Crematogaster AFRC_za01 & 2 & 0 & 0 & 0 & 2 & 0.02 & 0 & 0 & 0 & 0 & 0 & 0.00 & 2 & 0.01 \\
\hline Dorylus AFRC_za01 & 0 & 0 & 0 & 2 & 2 & 0.02 & 0 & 0 & 0 & 0 & 0 & 0.00 & 2 & 0.01 \\
\hline Pheidole AFRC_sz04 & 0 & 0 & 0 & 0 & 0 & 0.00 & 1 & 1 & 0 & 0 & 2 & 0.05 & 2 & 0.01 \\
\hline Cardiocondyla shuckardi & 0 & 0 & 0 & 0 & 0 & 0.00 & 0 & 1 & 0 & 0 & 1 & 0.03 & 1 & 0.01 \\
\hline$N$ & 4534 & 325 & 6169 & 1142 & 12170 & & 1178 & 740 & 1035 & 957 & 3910 & & 16080 & \\
\hline$S$ & 16 & 9 & 8 & 9 & 19 & & 15 & 12 & 7 & 11 & 17 & & 25 & \\
\hline Richness $d$ & 1.78 & 1.38 & 0.80 & 1.14 & 1.91 & & 1.98 & 1.67 & 0.86 & 1.46 & 1.93 & & 2.48 & \\
\hline Evenness $J$ & 0.22 & 0.65 & 0.10 & 0.008 & 0.31 & & 0.47 & 2.30 & 0.15 & 0.16 & 0.33 & & 0.33 & \\
\hline Shannon $H$ & 0.62 & 1.42 & 0.22 & 0.18 & 0.91 & & 1.28 & 0.74 & 0.28 & 0.39 & 0.95 & & 1.05 & \\
\hline
\end{tabular}

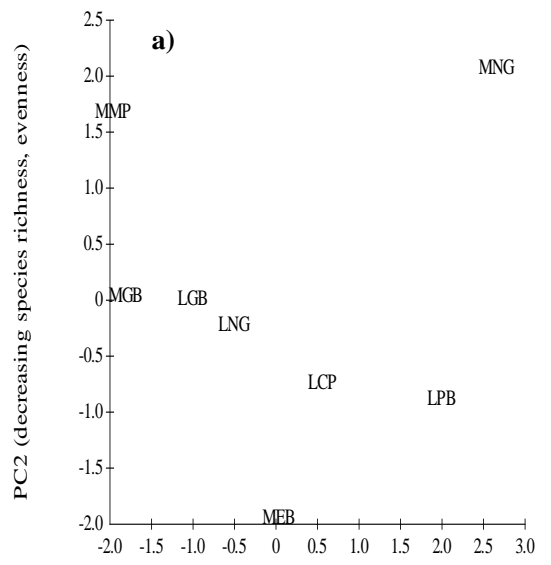

$\mathrm{PCl}$ (drecreasing total species, numbers and diversity)

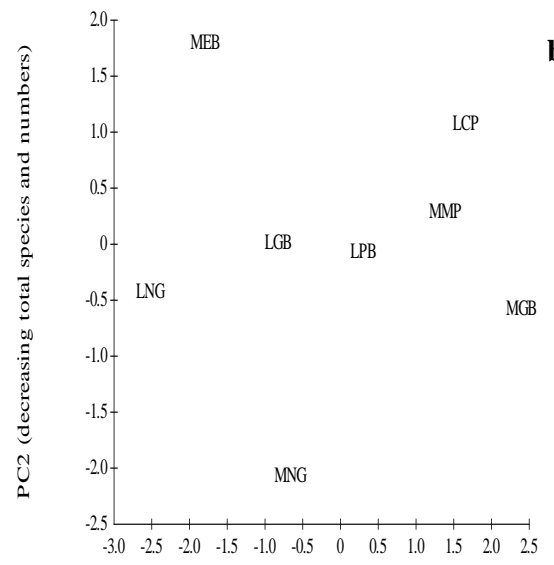

$\mathrm{PCl}$ (decreasing species diversity, evenness, richness)

Figure 3. PCA analysis of a) carabid beetle and b) ant diversity indices in al habitats 


\section{Species distribution between habitats}

Species composition for both Families was clearly distinct between habitats at both sampling locations $(\mathrm{R}=0.860 ; \mathrm{p}=0.001)$, as observed from the respective cluster analyses carried for both Families. There was very low similarity in carabid beetle species between sampling habitats. Figure $4 a$ shows separation of habitats from the two locations, with the pine border having only $3.34 \%$ similarity in carabid beetle species with the other habitats sampled. The next major branch in the dendogram is subsequently dominated by habitats from the respective locations, which had only $7.81 \%$ similarity, with the exception of the eucalyptus border habitat which was more similar to sampling habitats in the lowveld, probably due to similar habitat characteristics such as the low litter cover common between these.

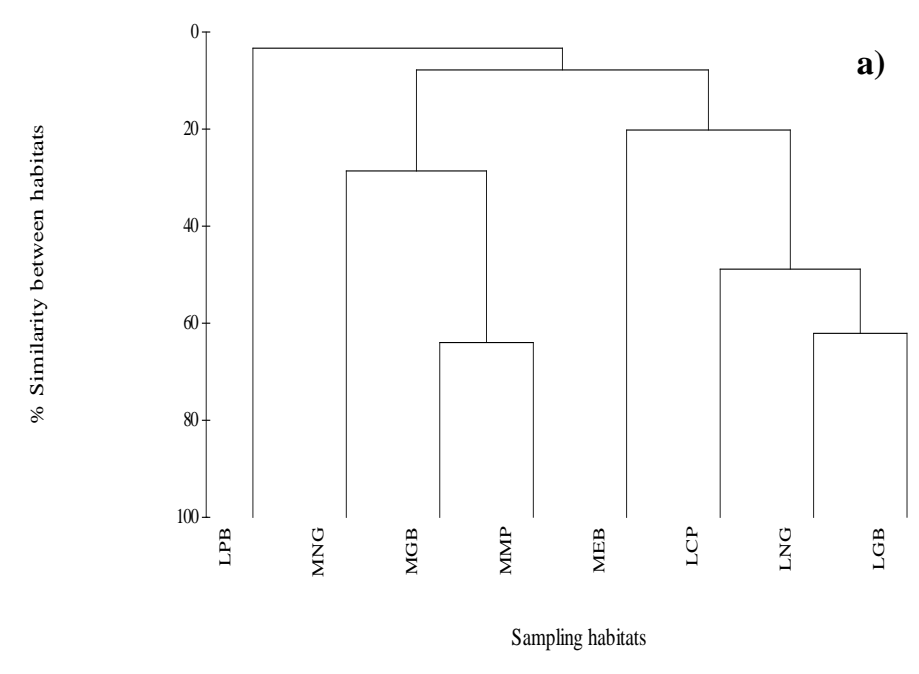

b)

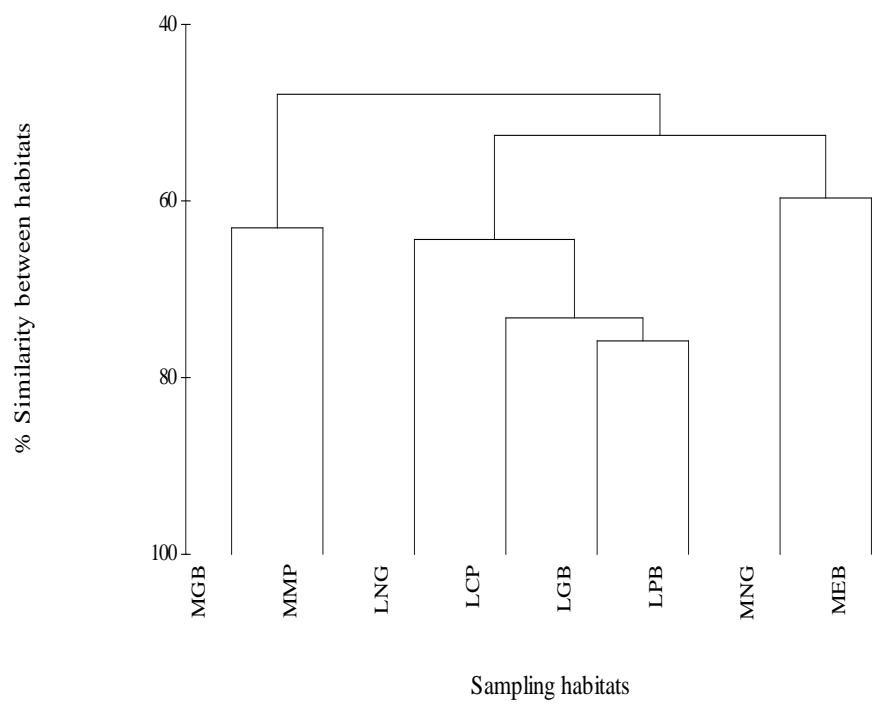

Figure 4. Dendogram showing similarity in a) carabid beetles and b) ant species distribution between sampling habitats 
A similar pattern was observed for the ants at the same location (Figure $4 b$ ) although similarity between habitats was comparatively higher, e.g. the maize plot and grass border shared $47.92 \%$ similarity with other habitats. The remaining middleveld and lowveld habitats had higher similarity at $52.56 \%$. For both Families, habitats within each location were more similar and tended to cluster together.

Further analyses were carried in SIMPER to determine if any of the species collected were typical of the sampling habitats, thus leading to the dendograms obtained. Analysis of carabid distribution indicated that overall dissimilarity between the two locations was $95.23 \%$ and this was due to four carabid species, i.e. A. cf percoides and $P$. tomentosus were collected only from the middleveld location while $C$. notabilis and $O$. mandibularis were unique to the lowveld. Carabid species occurrences also varied within the respective sampling habitats at each location. Habitats in the middleveld had low similarity of $26.87 \%$, and the dominant carabids at this location, i.e. A. cf percoides, $P$. tomentosus and C. cylindricollis were typical of only the grass border and maize plot, thus accounting for the low similarity with the other habitats. Similarity in carabid species between habitats was also comparable within lowveld habitats They had a similarity of $28.97 \%$, with the dominant species, i.e. $O$. mandibularis and $C$. notabilis being typical of the natural grassland and grass border.

Compared to the carabid species, the two locations had a lower dissimilarity of $51.61 \%$ for ant species composition since they had more species in common compared to the carabid beetles. The dissimilarity observed was attributed to A. custodiens, which was overwhelmingly collected from the middleveld (3971) compared to 63 from the lowveld as well as Pheidole, which was collected mainly from the lowveld (775) compared to 88 from the middleveld. Middleveld habitats were differentiated by Myrmicinae sp. and A. custodiens, resulting in similarity of $47.65 \%$. Myrmicinae sp. were predominantly from the grass border while A. custodiens was mainly in the natural grassland. Habitats in the lowveld had a higher similarity of $63.41 \%$, with the discriminating species being Myrmicinae sp. and Pheidole sp., predominantly from the cotton plot and natural grassland respectively.

Draughtsman plot indicated low correlation between habitat and soil characteristics measured except $\mathrm{pH}$ and temperature $(\sigma=0.937)$ and EA and OM $(\sigma=0.986)$. PCA analysis of the habitat variables indicated that $72.7 \%$ of the variables was captured, with $49.5 \%$ in the first axis and $23.3 \%$ along the second axis. The first axis was dominated by decreasing $\mathrm{OM}$, insolation and EA and increasing $\mathrm{pH}$ while the second axis was dominated by increasing $\mathrm{N}$, decreasing $\mathrm{P}$ and rainfall (Figure 5).

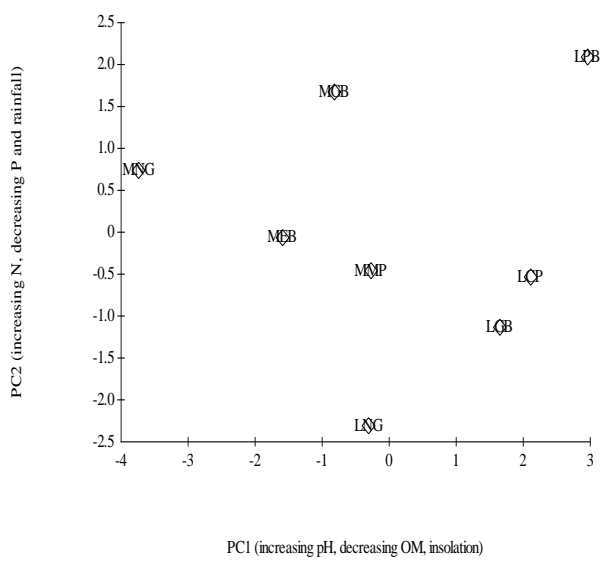

Figure 5. PCA for environmental variables measured at the two sampling locations 
The other variables measured did not feature significantly within the 2-dimensional plot. The carabid beetles had no significant correlation with any of the habitats variables measured, while the ants had a significant correlation with OM content $(\sigma=0.6607, \mathrm{p}=0.0044)$.

\section{Discussion}

\section{Habitat characteristics}

The habitats sampled supported a number of carabid and ants species, as expected of diverse agroecosystems. Diverse agroecosystems, as characterised by high heterogeneity, have the capacity to maintain high arthropod diversity (Peck et al., 1997). However, management practices have an impact on a habitat's ability to sustain its biological diversity. Fallow and unmanaged habitats have a positive effect on macroinvertebrate taxa within a heterogeneous landscape and this was observed in this study where the unmanaged habitats like the grass borders and natural grass had high numbers of individuals as well as species diversity despite being embedded in a matrix of managed habitats (Perfecto et al., 1997). For the two Families assessed, carabid beetle populations were highest in the maize plot and adjacent grass border while ant populations were highest in the grass border and natural grassland in middleveld habitats. At the lowveld, carabid beetle populations were highest in the natural grassland and grass border while ants were highest in the natural grass land and cotton plot. The differences in numbers and species between habitats sampled demonstrate that the various habitat patches assessed contribute to species diversity and conservation and therefore their importance as refugia for insect species. These habitat patches provide an abundant diversity of food, nesting and hiding places for ground arthropods such as ants and carabid beetles thus maintaining high diversity despite transformations of the surrounding landscape due to human activity (Perfecto et al., 1995; Goehring et al., 2002). Locally, similar results were observed in a similarly fragmented agricultural landscape, where coccinellid beetles occurred in higher numbers within managed citrus orchards, probably due to prey availability, while carabid beetles were higher in natural habitats (Magagula and Samways, 2001; Magagula, 2003). Such differences in species distribution relative to management practices emphasises the need to study more than one taxonomic group within landscapes modified by human activity.

The high numbers collected from the maize and cotton plots also emphasises that managed habitats also have a role to play in insect conservation despite anthropogenic transformation. Although habitats such as the eucalyptus and pine borders had low numbers and diversity, the majority of habitat variables measured had no correlation with the insect populations. In this study, only the ant populations had a significant correlation with OM content, as observed in other studies (Dauber et al., 2005). The primary determinant of the insect populations assessed is thus the type of management, with habitats where no management practises were carried out having higher populations and insect diversity, as in the natural grasslands and borders. It is the management practices within these habitats which determine their impact relative to invertebrates (Perfecto et al., 1997; Tsharntke et al., 2005), e.g. dung beetle communities are affected by intensified agriculture (Barragon et al., 2011). Comparatively, the cotton plot, which had weeding and pesticide applications, had the lowest total number of species and richness overall. This implies that the structure and character of a habitat are important in influencing the ecological value for ground dwelling predators, particularly with regard to shelter, microclimate and mobility 
(Melnychuk et al., 2003). The high numbers of carabid beetles within the maize plot could also have been due to the presence of shelter since various weed species, such as black jack, grass and Desmodium sp. were abundant in the absence of weeding (Weibull, 2003). Weeds provide high plant diversity and maintain arthropod diversity despite transformation for agricultural purposes (Perfecto et al., 1997; Melnychuk et al., 2003). The low correlation with the majority of variables measured implies that other factors not measured in this study may thus also contribute to insect species occurrences within habitats.

Borders between distinct habitat patches are known to be important for species movement between isolated habitats within a fragmented, heterogeneous landscape by serving as natural pathways between habitats (Magagula, 2003; Weibull et al., 2003). These remain important particularly in agroecosystems where habitats are divided into smaller, isolated remnants (Paolucci et al., 2012) thus acting as ecological corridors which reduce the detrimental effects of isolation between remnants in heterogeneous landscapes as well reducing isolation of populations within such landscapes. Borders and adjacent plots, like the maize plot and grass border in the middleveld, had species in common due that habitat islands usually have species in common with the surrounding matrix (Lovei et al., 2006). However, this study demonstrated that, while there may be movement between habitat patches, insect species can also be restricted within specific habitats, particularly carabid beetles, due to varying levels of adaptability within the landscape.

\section{Species occurrences}

Both sampling locations had species with variable levels of adaptability in the habitats sampled within the two Families surveyed. In the middleveld, carabid beetles were highly adaptable, whereby they established in recently disturbed habitats like the maize plot as well as undisturbed habitats like the grass borders, e.g. A. cf percoides, $C$. cylindricollis while other species like A. optimus, Brachinus sp. were restricted the natural grass border. In the lowveld, however, carabid beetles were less adaptable since they were collected primarily in undisturbed habitats, i.e. the natural grassland and grass border e.g. C. notabilis, O. mandibularis, Progonochaetus sp., C. cf pulchellus. Such differences between the locations emphasises the need for further study on carabid beetle ecology (Rainio, 2012) within the southern hemisphere as such studies have been mainly in landscapes in the northern hemisphere (New, 1998).

Alternately, ants illustrated generalist behaviour, with a few species in common at both sampling locations and similar habitat preferences, e.g. morphospecies no. 11 was only found in the natural grassland at both locations while A. custodiens was a generally found in all the habitats sampled at both locations. However, in the middleveld, this Family was less adaptable since they occurred in significantly higher numbers within undisturbed habitats, e.g. the grass border and natural grassland had significantly higher ant populations overall. Although generally widespread, the populations tended to be higher in certain habitats, e.g. morphopecies no. 1, Camponotus AFRC-za42 and Camponotus AFRC_za12 were found predominantly in the grass border while $A$. custodiens, L. intermedia, T. notiale were predominantly in the natural grassland. The natural grassland habitat had a few species unique to it, e.g. N. natalensis, Leptogynys schwabi, Cataulacus traegaordo and morphospecies no. 11 were not found in the other habitats sampled in the middleveld. Although the lowveld largely had generalist species, certain species also exhibited habitat preferences, e.g. Camponotus AFRC_za12 was 
found primarily in the grassland and grass border like in the middleveld, while $O$. troglodyte, T. sericeiventre, C. mayri were found only in the natural grassland.

These results indicate that the two Families had distinct patterns in species distribution at both sampling locations, including habitat loyalty, thus the high dissimilarity between locations and habitats observed. Carabid beetles were delineated by geographical location, with six species occurring only in middleveld habitats, three only in lowveld habitats and none (with more than a single occurrence) in common between the two locations. Ants had generalists as well as location specific species, e.g. Morphospecies no.1, A. custodiens, Pheidole sp. and Camponotus AFRC_za12 are some species these two locations had in common and those with restricted occurrence as described above. These results may suggest that ants could be better suited as indicator species since species which have a range of ecological states have been suggested to be more useful as indicators of environmental change than highly specific species with restricted distribution (Longino et al., 2002; McGeoch et al., 2002) such as the carabid beetles, particularly in agroecoystems where disturbances are not severe (Andersen and Majer, 2004). Ants are diverse and occur in any habitat type and although disturbed by agricultural practices, they recover quickly from these (Folgarait, 1998).

\section{Conclusions}

Habitat structure is an important component for many species and the spatial pattern of habitats has a major impact on maintenance of biological diversity and ecosystem function. Both Families assessed have important roles in ecosystem function, e.g. predation, seed dispersal etc. (Goehring et al., 2002; Gibb, 2012) and their conservation is of critical importance in agroecosystems thus the need for the maintenance of heterogeneous habitat patches. From this study, carabid beetle populations were affected by land use features while ants by habitat characteristics such as insolation and organic matter content (Dauber et al., 2005). There was no correlation between ants and carabids as observed in other studies (Andersen, 1995; Oliver and Beattie, 1996) where no correlation was observed between ants, beetles and spiders. Ultimately, the results suggest that habitat quality, as determined by land use, microclimate and soil characteristics need to be secured for insect species conservation, in addition to landscape heterogeneity (Dauber et al., 2005; Weibull et al., 2003) since they are important determinants of insect species occurrence, e.g. litter is significant in the maintenance of species diversity and richness (Magura et al., 2000). Depending on issues at hand, both Families thus have the potential to be used as environmental indicators due to their close abundance, diversity and close relation with habitat quality, (Peck et al., 1998; Magura et al., 2000; Andersen et al., 2002; Raino, 2012; Rosado et al., 2013). Determination of the use of these insect as indicators, however, needs further assessment over longer term to ascertain their sensitivity to change as well as their response to these changes within specific environments (Peck et al., 1998). The restriction to certain types of habitats illustrated by the species in this study, illustrates that habitat fidelity may be reflective of diversity of available habitats and human impacts within the landscape studied (Magagula and Samways, 2001). Considerations of more than one taxonomic group is thus essential since conservation strategies aimed at optimising species richness for one taxonomic group in agricultural landscapes will not automatically increase the species richness nor be representative of other groups (Weibull et al., 2003; Gerlach et al., 2013). 


\section{REFERENCES}

[1] Andersen, A.N. (1995): A classification of Australian ant communities, based on functional groups and parallel plant life-forms in relation to stress and disturbance. Journal of Biogeography 22: 15-29

[2] Andersen, A.N., Hoffman, B.D., Müller, W.J., Griffiths, A.D. (2002): Using ants as bioindicators in land management: simplifying assessment of ant community responses. Journal of Applied Ecology 39: 8-17

[3] Andersen, A.N., Majer, J.D. (2004): Ants show the way Down Under: invertebrates as bioindicators in land management. - Frontiers in Ecology and the Environment 2:291-298

[4] Barragán, F, Moreno, C.E., Escobar, F., Halffter, G., Navarrete, D. (2011): Negative impacts of human land use on dung beetle functional diversity. - PLoS ONE 6(3): e17976. doi:10.1371/journal.pone.0017976

[5] Dauber, J., Purtauf, T., Allspach, A. Frisch J., Voigtländer, K., Wolters, V. (2005): Local vs. landscape controls on diversity: A test using surface-dwelling soil macroinvertebrates of differing mobility. - Global Ecology and Biogeography 14: 213-221

[6] Folgarait, P.A. (1998): Ant biodiversity and its relationship to ecosystem functioning: a review. - Biodiversity and Conservation 7:1221-1244

[7] Gerlach, J., Samways, M., Pryke, J. (2013): Terrestrial invertebrates as bioindicators: an overview of available taxonomic groups. - Journal of Insect Conservation 17: 831-850

[8] Gibb, H. (2012): Effects of planting method on the recovery of arboreal ant activity on revegetated farmland. - Austral Ecology 37: 789-799

[9] Goehring, D.M., Daily, G.C., Sekerçioğlu, C.H. (2002): Distribution of ground-dwelling arthropods in tropical habitats. - Journal of Insect Conservation 6:83-91

[10] Magagula, C.N. (2003): Changes in carabid beetle diversity within a fragmented agricultural landscape. - African Journal of Ecology 41: 23-40

[11] Magagula, C.N., Samways, M.J. (2001): Maintenance of ladybeetle diversity across a heterogenous African agricultural savanna land mosaic. - Biodiversity and Conservation 10: $209-222$

[12] Magura, T., Tóthmérész , B., Bordán, Z. (2000): Effects of nature management practice on carabid assemblages (Coleoptera: Carabidae) in a non-native plantation. - Biological Conservation 93: 95-102

[13] McGeoch, M.A., Van Rensburg, B.J., Botes, A. (2002): The verification and application of bioindicators: A case study of dung beetles in a Savanna ecosystem. - Journal of Applied Ecology 39: 661-672

[14] Melnychuk, N.A., Olfert, O., Youngs, B., Gillot, C. (2003): Abundance and diversity of Carabidae (Coleoptera) in different farming systems. - Agriculture, Ecosystems and Environment 95: 69-72

[15] New, T.R. (1998): The role of ground beetles (Coleoptera: Carabidae) in monitoring programmes in Australia. - Ann. Zool. Fennici 35: 163-171

[16] Oliver, I., Beattie, A.J. (1996): Designing a cost-effective invertebrate survey: A test of methods for rapid assessment of biodiversity. - Ecological Applications 6: 594-607

[17] Paolucci, L.N., Solar, R.R., Sobrinho, T.G., Sperber, C.F., Schoereder, J.H. (2012): How does small-scale fragmentation affect litter-dwelling ants? The role of isolation. Biodiversity and Conservation 21:3095-3105

[18] Peck, S.L., McQuaid, B., Campbell, C.L. (1998): Using ant species (Hymenoptera: Formicidae) as a biological indicator of agroecosystem condition. - Environmental Entomology 27: 1102 - 1110

[19] Perfecto, I., Vandermeer, J., Hanson, P., Cartín, V. (1997): Arthropod biodiversity loss and the transformation of a tropical agro-ecosystem. - Biodiversity and Conservation 6: 935-945 
[20] Raino, J. (2012): Distribution and community composition of carabid beetles (Coleoptera: Carabidae) in Ranomafana National Park, Madagascar. - International Journal of Insect Science 32:69-77

[21] Rosado, J.L.O., Gonçalves de Gonçalves, M., Dröse, W., Ely e Silva, E., Krüger, F., Loeck, A.E. (2013): Effect of climatic variables and vine crops on the epigeic ant fauna (Hymenoptera: Formicidae) in the Campanha region, state of Rio Grande do Sul, Brazil. - Journal of Insect Conservation 17: 1113-1123

[22] Tsharntke, T., Klein, A.M., Kruess, A., Steffan-Dewenter, I., Thies, C. (2005): Landscape perspectives on agricultural intensification and biodiversity - ecosystem service management. - Ecology letters 8: 857-874

[23] Underwood, E.C., Fisher, B.L. (2006): The role of ants in conservation monitoring: If, when and how. - Biological Conservation 132:166-182

[24] Weibull, A., Östman, Ö., Granqvist, Å. (2003): Species richness in agroecosystems: the effect of landscape, habitat and farm management. - Biodiversity and Conservation 12:1335-1355

\section{APPENDIX}

Electronic Appendix: Original Data 